\title{
Validity and Reliability of a Turkish Version of the Relationship and Sexuality Scale for Kidney Transplant Recipients
}

\author{
Böbrek Nakli Alıcılarında İlişki ve Cinsellik Ölçeği’nin \\ Türkçe Versiyonunun Geçerlik ve Güvenirliği
}

Merve GÖNÜL AKKOÇ ${ }^{1}$, Nilgün AKSOY ${ }^{2}$

${ }^{1}$ Kepez State Hospital, Department of Nursing, Antalya, Turkey

${ }^{2}$ Akdeniz University Faculty of Nursing, Department of Surgical Nursing, Antalya, Turkey

Correspondence Address Yazışma Adresi

\section{Nilgün AKSOY}

Department of Surgical Nursing, Akdeniz University Faculty of Nursing, Antalya, Turkey

E-mail:

nilgunmutluaksoy@akdeniz.edu.tr

\begin{abstract}
Objective: The aim of this study was to evaluate the validity and reliability of Relationship and Sexuality Scale for kidney transplant recipients in Turkey.

Material and Methods: This methodological study was conducted with 150 kidney transplant recipients applied to transplant center of a university hospital between November 2016 and February 2017. "Patient Identification Form", "Relationship and Sexuality Scale" and "The Arizona Sexual Experiences Scale" were used as data collection instruments. The data were analyzed on SPSS 23 through numbers, percentage, mean, standard deviation, content validity index, factor analysis, correlation analysis and coefficient alpha. The validity of the scale was tested using the content validity index and confirmatory and exploratory factor analyses. The process of adaptation and translation of instruments by World Health Organization was followed to provide language validity. Expert opinion was received for content validity and it was found to be coherent. The questionnaire's factor structure demonstrated good fit, implying that it could be applied to the Turkish kidney transplant recipients population.
\end{abstract}

Results: The scale consisted of three sub-dimensions according to validity testing. None of the original items were excluded. The general cronbach's alpha coefficient of the scale was found 0.84 . The principal components analysis revealed 3 factors explaining $66.40 \%$ of the variance. Correlations between item-total correlation and sub-dimensions were found positive, medium-level and statistically significant $(\mathrm{p}<0.01)$.

Conclusion: Content validity, construct validity, and reliability analyses of the Relationship and Sexuality Scale revealed that the scale may be used to measure relationships and sexuality of kidney transplant recipients in Turkey.

Keywords: Kidney transplantation, Relationship and sexuality scale, Validity, Reliability

\section{öz}

Amaç: Bu çalışmanın amacı; böbrek nakli alıcılarında İlişki ve Cinsellik Ölçeği’nin Türkiye'de geçerlik ve güvenirliğini değerlendirmektir.

Gereç ve Yöntemler: Metodolojik tipte olan bu çalışma Kasım 2016-Şubat 2017 tarihleri arasında bir Üniversite Hastanesi'nin Organ Nakli Polikliniği'ne bașvuran 150 böbrek nakli alıcısı ile yapılmıştır. Veri toplama araçları olarak "Hasta Tanılama Formu", "İlişki ve Cinsellik Ölçeği”" ve "Arizona Cinsel Yaşantılar Ölçeği” kullanılmıştır. Veriler, SPSS 23 paket programında sayı, yüzde, ortalama, standart sapma, içerik geçerliği, faktör analizi, korelasyon analizi, cronbach alfa katsayısı hesaplanarak analiz yapılmıştır. Ölçeğin geçerliliği, kapsam geçerlilik indeksi ve doğrulayıcı ve açıklayıcı faktör analizleri kullanılarak test edilmiştir. Ölçek uyarlama dil geçerliğinde Dünya Sağlık Örgütü’nün önerdiği ölçeklerin adaptasyon ve çeviri süreci prosedürü izlenmiștir. Anketin faktör yapısı, Türk böbrek nakli alıcı popülasyonuna uygulanabileceğini ima ederek iyi bir uyum göstermiştir.

Bulgular: Geçerlik analizi sonucunda ölçeğin 3 alt boyuttan oluştuğu belirlenmiştir. Orijinal ölçekten madde çıkarılmamıştır. Ölçeğin genel Cronbach alfa katsayısı 0.84 olarak bulunmuştur. Temel bileşenler analizi, varyansın \%66.40’ını açıklayan 3 faktörü ortaya çıkarmıştır. Ölçeğin madde toplam puan korelasyonları ve alt boyutları arasındaki korelasyonları pozitif yönde, orta düzeyde ve istatistiksel olarak anlamlı $(\mathrm{p}<0.01)$ olduğu saptanmıştır.

Sonuç: İlişki ve Cinsellik Ölçeği'nin içerik geçerliğii, yapı geçerliği ve güvenilirlik analizleri, ölçeğin böbrek nakli alıcılarında ilişki ve cinselliği ölçmek için Türkiye'de geçerli ve güvenilir bir araç olarak kullanılabileceğini ortaya koydu.

Anahtar Sözcükler: Böbrek nakli, İlişki ve cinsellik ölçeği, Geçerlik, Güvenirlik 


\section{INTRODUGTION}

Chronic kidney disease is an important public health problem (1), with $8-10 \%$ of the adult population having some form of kidney damage (2). According to the Turkish Society of Nephrology Registry Report, end-stage renal disease (ESRD) prevalence is 957 per million population in Turkey in 2017 (3). Kidney transplant is the gold standard treatment for ESRD in terms of survival, health costs, and quality of life (4). In 2017, the number of patients in Turkey who underwent a kidney transplant (KT) was reported as $3342(3)$.

The World Health Organization (WHO) defines "sexual health is not only the absence of disease, dysfunction, or infirmity, but also relates it to physical, emotional, mental and social well-being" (5). Sexual health is an integral part of the concept of general health, and it interacts with physical, emotional, social and mental factors (6). A study by Sabanciogullari et al. (7) observed that $85.6 \%$ of participants with ESRD experienced sexual dysfunction. However, KT is reported to increase sexual health due to the correction of hormonal disorders $(8,9)$.

Sexual dysfunction is a common health problem observed in chronic kidney disease, and it is reported to persist in $50 \%$ of cases after transplantation (8). Specifically, sexual dysfunction observed among $\mathrm{KT}$ patients can cause various physiological and psychological effects (10). According to a study conducted in Turkey, $49.6 \%$ of kidney transplant recipients were between 20 and 44 years old (11). Therefore, sexual function and fertility in patients remain important. Pertuz et al. (2014) (12) determined that fewer than $10 \%$ of studied patients suffered from decreased sexual satisfaction following a KT.

The etiology of the patients with ESRD typically includes diseases as hypertension (32\%) and diabetes mellitus (40\%) (13). Therefore, although a successful KT manages erectile dysfunction and increases sexual desire, varying degrees of sexual dysfunction may persist among many patients (14). However, among the available treatments for ESRD, KT is the most effective option for improving overall health and sexual function (15). Erectile dysfunction is defined as an inability to sustain and maintain an erection sufficient for satisfactory sexual intercourse $(15,16)$. The prevalence of erectile dysfunction among ESRD patients ranges from 50 to $80 \%$ (16). Providing an appropriate enterprise for patients suffering from sexual issues following $\mathrm{KT}$ is one of the basic responsibilities of nurses (17).

In order to provide holistic care to KT patients, nurses must understand patients' sexuality, fear, anxiety, and concern. However, similar to other societies, sexuality is not a comfortable topic in Turkey. Therefore, nurses should strengthen the mechanisms by which KT recipients cope with sexual issues. The ultimate goal is to improving of the adaptation to the posttransplant process of KT recipients.

A valid and reliable measurement tool is required to determine the relationship and sexuality status of KT recipients as well as to plan training to be given to the patients on this subject. Therefore, the aim of this study was to translate and cross-culturally adapt the Relationship and Sexuality Scale into Turkish and evaluate the psychometric properties of the Turkish version of the RSS (RSS-Tr).

\section{METHODS}

\section{Study design and sample}

The present study used a methodological design aimed at assessing the psychometric properties of the Relationship and Sexuality Scale (RSS) in a Turkish sample. Thus, the research questions were as follows:

1. Is the Turkish version of the RSS valid?

2. Is the Turkish version of the RSS reliable?

The sample consists of patients who applied to the transplant center of a university hospital in south of Turkey and met the inclusion criteria of the study. It has been noted that "sample size should be five to ten times as high as the number of items recommended in validity and reliability studies" (18). The scale was calculated as 15 times the number of items. Overall, $150 \mathrm{KT}$ recipients created the study sample since the scale has 10 items. The sexual fear sub-dimension of the RSS includes questions that include the last 2 weeks. Since sexuality may vary according to time, testretest method cannot be evaluated in this scale. Therefore, in this study, the Arizona Sexual Experiences Scale (ASEX) was used within the context of concurrent validity for adaptation of the RSS to Turkish. The sample consisted of 75 females and 75 males since the female/male forms of the ASEX are evaluated separately. The sample included volunteers over 18 years old who provided written consent, had an active sexual life, were literate in Turkish, passed the first six months of KT surgery, and were capable of self-expression within a healthy cognitive development.

Data collection occurred between November 2016 and March 2017 until the required sample size was achieved.

\section{Ethical issues and data collection}

Permission was obtained from the authors who developed the scale to use the scale. In order to conduct the study, approval was obtained from the Akdeniz University Faculty of Medicine Clinical Research Ethics Committee (decision no. 2016/427), and written permission was obtained from the hospital where the study was conducted. The aim of the study was explained to those complying with the sample criteria. Written and verbal approval was obtained from the participants. 


\section{Instruments}

\section{Patient identification form}

A patient identification form was created based on the literature and includes sociodemographic variables (age, sex, educational level, length of marriage, income, etc.) and clinical variables (elapsed time after KT surgery, donor type, etc.) $(7,8)$.

\section{Relationship and Sexuality Scale-RSS}

The RSS is a general scale was developed that evaluates patients' sexual relationships according to the field of use. It was developed by Berglund et al. in Sweden in 2001. The scale was first implemented for female patients with breast cancer $(n=80)$ and consists of questions regarding patients' sexual function, frequency of sexual intercourse, and sexual fears over the past 2 weeks (19). The language of the scale is English, and it consists of 10 items. Cronbach's alpha (a) value was 0.80 for the entire scale, 0.86 for sexual function, 0.82 for sexual frequency, and 0.77 for sexual fear (20). Kazemi-Saleh et al. (2008) (20) used the scale for patients with ischemic heart disease, while Tavallaii et al. (2009) (21) used it for the hemodialysis and KT recipients, and Ryan et al. (2015) (22) used it for patients with psoriasis. The scale is evaluated through total score (0-36) and three sub-dimensions. These sub-dimensions include sexual function (0-16), sexual frequency (0-12), and sexual fear (0-8). Questions $1-3,7$, and 8 determine sexual function, while questions 4,9 , and 10 determine sexual frequency, and questions 5 and 6 determine sexual fear. Questions 1, 4, 5, 6, 9, and 10 are scored between 0 to 4 , while 0 to 3 points are allotted for questions 2, 3, 7, and 8. Lower scores indicate stronger relationships and sexuality, while higher scores show the existence of sexual dysfunction $(21,23)$.

\section{Arizona Sexual Experiences Scale-ASEX}

In the present study, the ASEX was used to provide concurrent validity for adaptation of the RSS from English to Turkish.

The ASEX is a self-administered scale developed to identify and evaluate "changes and disorders in sexual function of patients taking psychotropic drugs" by McGahuey et al. (2000) (24), and the Cronbach's alpha value for the scale was 0.91 . A Turkish validity and reliability study was conducted with patients undergoing hemodialysis $(\mathrm{n}=25$ males and $n=18$ females). Internal consistency and reliability were high, with Cronbach's alpha values of 0.89 and 0.90 . These results were determined to be valid in the differentiation of sexual dysfunction disorders. The ASEX is a five-item rating scale that consists of two separate forms (female and male). Questions examine "drive, arousal, penile erection/ vaginal lubrication, ability to reach orgasm and satisfaction with orgasm". If the total score of the scale is 19 or above, or if any question scores 5 or 6 points, or if three or more questions score 4 points, it indicates sexual dysfunction (25).

\section{Study procedure}

The validity and reliability of this study were tested using the four steps discussed below.

\section{Linguistic validity}

The adaptation and translation process determined by the WHO was followed for studies aimed at adapting the RSS to Turkish for KT recipients (26). This process involved translation of the scale from English into Turkish, which was performed by a health professional who is a native Turkish speaker that has a strong knowledge of both languages as well as Turkish culture and terminology. The adapted scale was evaluated by an expert panel consisting of health professionals, a translator and researchers. The scale was translated back into English by a native translator who also speaks Turkish and has no knowledge of the RSS and original text. The two translations were then compared to determine possible differences. This translated scale is now referred to as the RSS-Tr. The level of clarity was determined through the preliminary implementation of the scale, whose language validity was confirmed for $10 \mathrm{KT}$ recipients with characteristics similar to the target group complying with the sample criteria. KT recipients who were taken into the preliminary implementation were not included in the sample. In this preliminary implementation, participants were asked whether there were any incoherent expressions, words, or inappropriate content in the RSS-Tr. Notably, all statements were understood by participants.

\section{Gontent validity}

The scale was submitted to the opinion of 10 experts, which included 5 nursing assistant professors, 1 general surgeon, 1 nephrologist, 1 transplant nurse, 1 psychiatrist, and 1 transplant coordinator. Content Validity Index (CVI) was used to evaluate the expert opinions. Experts scored the scale with either 1 (many changes required), 2 (a few changes required), 3 (appropriate), and 4 (absolutely appropriate). In the literature, an average CVI score of 0.80 or more has been reported as acceptable (18).

\section{Construct validity}

The Kaiser-Meyer-Olkin (KMO) and Barlett's Test were used to determine whether the sample size was sufficient. A KMO value above 0.50 indicates a sample size sufficient for factor analysis (18). Confirmatory factor analysis involves testing the suitability of the structures determined by the exploratory factor analysis to the conceptual or assumed factor structures (27). Explanatory factor analysis (EFA) and confirmatory factor analysis (CFA) were conducted for the purpose of testing the construct validity. In confirmatory factor analysis, the chi-square fit test, chi-square/ 
degree of freedom, root mean square error of approximation (RMSEA), standardized root mean square residual (SRMR), comparative fit index (CFI), nonnormed fit index (NNFI), and goodness of fit index (GFI) was calculated.

If a measuring instrument whose validity is examined yields similar results comparison to another instrument whose validity has already been proved, it means that the instrument is criterion validity. The two most common validity criteria are concurrent validity and predictive validity (28). In this research, concurrent validity was evaluated by correlation analysis.

\section{Reliability}

Item-total correlation and Cronbach's alpha were used to test the reliability of the RSS-Tr. The fact that the sub-dimensions of the scale measure the same feature, the scale has internal consistency. The alpha coefficient is a measure of the internal consistency of the items in the scale. Cronbach's alpha coefficient varies between 0 and 1, with a coefficient between 0.60-0.79 being considered "quite reliable in scale" and a coefficient between $0.80-1.00$ being considered "highly reliable" (28).

\section{Pre-application}

Following content validation by experts, the scale was re-tested by pre-application to $8 \mathrm{KT}$ recipients. The data collection form and scale were found to be easily understandable by patients and no changes were required. Pre-application data were not involved in the study.

\section{Implementing data collection forms}

Research data were collected using a sealed envelope system. The patient identification form, RSS-Tr, and ASEX were completed by the patients. The patients deposited the completed forms in a closed envelope into a box created by the researchers. It took an average of 15-20 minutes to complete the data collection form by the patients.

\section{Data analysis}

The data were analyzed using IBM SPSS Statistics for Windows (version 23) by calculating percentages, means, standard deviations, CVI. For the internal criterion validity, the difference between the lower and upper group mean scores was analyzed by the significance test ( $\mathrm{t}$ test), correlation analysis was performed for concurrent validity, internal consistency (Cronbach's alpha) were used for reliability, and factor analysis was used for construct validity. EFA and CFA were conducted for the construct validity and Cronbach's alpha coefficients. $a<0.05$ was considered significant.

\section{RESULTS}

The present study involved a total of $150 \mathrm{KT}$ recipients. The mean age of the patients was $37.95 \pm 10.79$ and $50 \%$ were male. Overall, $37.3 \%$ of the patients were primary school graduates, $46.7 \%$ were income expense equal, and $67.3 \%$ were not working. In total, $57.3 \%$ of the patients underwent dialysis before transplantation and received an average of $38.10 \pm 48.16$ months of dialysis treatment. Moreover, $84.7 \%$ of the patients received kidneys transplanted from live donors. The mean time after KT was $62.73 \pm 57.16$ months (Table 1).

The mean overall score of the RSS-Tr was $15.31 \pm 6.86$ (min:0, max:34), while the mean score for the sexual function sub-dimension was $6.54 \pm 3.59$ (min:0, max:16), the mean score of the sexual frequency sub-dimension was $6.27 \pm 2.82$ (min:0, max:12), and the mean score of the sexual fear sub-dimension was 2.54 \pm 2.31 (min:0, max:8) (Table 2).

Table I: Sociodemographic and introductory features of Kidney Transplant recipients $(\mathrm{n}=150)$.

\begin{tabular}{lcc}
\hline Sociodemographic features & n & \% \\
\hline Gender & & \\
\hline Female & 75 & 50 \\
\hline Male & 75 & 50 \\
\hline Education Status & 56 & 37.33 \\
\hline$\quad$ Primary school graduate & 26 & 17.33 \\
\hline$\quad$ Secondary school graduate & 37 & 24.67 \\
\hline$\quad$ High school graduate & 31 & 20.67 \\
\hline$\quad$ University graduate & 67 & 44.67 \\
\hline Income status & 13 & 8.67 \\
\hline$\quad$ Income lower than expenses & 70 & 46.67 \\
\hline$\quad$ Income more than expense & 101 & 67.33 \\
\hline Income expense equal & 34 & 22.67 \\
\hline$\quad$ Norking Status & 15 & 10.00 \\
\hline$\quad$ Working full time &
\end{tabular}

\begin{tabular}{lll}
\hline $\begin{array}{l}\text { Taking dialysis treatment before } \\
\text { transplantation }\end{array}$ & & \\
\hline Yes & 86 & 57.33 \\
\hline No & 64 & 42.67 \\
\hline
\end{tabular}

\section{Donor Feature}

\begin{tabular}{lcc}
\hline \multicolumn{1}{c}{ Living donor } & 127 & 84.67 \\
\hline \multicolumn{1}{c}{ Cadaveric donor } & 23 & 15.33 \\
\hline & Mean \pm SD \\
\hline Age & $37.95 \pm 10.79$ \\
\hline Dialysis Time (Month) & $38.10 \pm 48.16$ \\
\hline $\begin{array}{l}\text { Elapsed Time After Kidney Transplant } \\
\text { (Month) }\end{array}$ & $62.73 \pm 57.16$ \\
\hline
\end{tabular}

SD: Standard deviation. 


\section{Content validity}

For the present study, the language expression item index was 1.00 and the scope-item content index was 0.95 . According to the expert evaluation results, the lowest and highest item scores for the RSS-Tr were 0.9 and 1 . According to these results, the content validity of RSS-Tr is evaluated as "highly valid".

\section{Construct validity}

The chi-square $\left(\chi^{2}\right)$ statistic was determined to be the minimum fit function $\chi^{2} /$ degree of freedom $(d f), \chi^{2} / d f=1.61, \chi^{2 /}$ $d f<2$. The RMSEA was 0.07 , the SRMR was 0.05 , and both values were $<0.08$. GFI was 0.94 and adjusted GFI (AGFI) was 0.89. CFI was 0.97 and was found greater than 0.90 . Following these statistical evaluations, it was concluded that the original factor structure was confirmed (Table $3)$.

KMO and Bartlett's Test was used to verify sufficient sampling for Factor Analysis. The KMO coefficient was 0.84, which indicated that it was appropriate to conduct factor analysis, as the value above 0.50 . The result of sphericity from Bartlett's test was examined and was determined to be statistically significant $(\chi 2=589.56 ; p=0.000)$.
The three sub-dimensions were similarly obtained in the RSS-Tr as the original RSS. The lowest load factor was observed for item 4 (0.51) and the highest was observed for item 6 (0.87) (Table 4). The sexual function sub-dimension explains $30.7 \%$ of the total variance of the feature measured through this scale, while sexual frequency explains $18.1 \%$, and sexual fear explains $17.6 \%$. All three factors account for $66.4 \%$ of the total variance (Table 4 ).

\section{Reliability}

The reliability coefficient of the scale ranged between 0.60 and 0.86 on table 2 according to the results of internal consistency reliability tests. The general alpha reliability coefficient of the RSS-Tr was 0.84, thus indicating "high reliability" (Table 2).

The item-total correlations of the RSS-Tr are provided in Table 5. Item-total correlation ranged between 0.45 and 0.77 , with positive, medium-level, and statistically significant correlations being observed. Additionally, mutual correlations of sub-dimensions and correlations with total scale scores were also calculated. Correlations between the subdimensions were positive, medium-level and statistically significant $(p=0.000)$ (Table 5).

\section{Table II: Cronbach's Alpha Values of the RSS-Tr and Sub-dimensions (n=150).}

\begin{tabular}{lcc}
\hline Relationship and Sexuality Scale & Gronbach's Alpha & Mean \pm SD $(\min -\mathbf{m a x})$ \\
\hline Factor $1^{*}$ & 0.86 & $6.54 \pm 3.59(\min : 0, \max : 16)$ \\
\hline Factor $2^{* *}$ & 0.60 & $6.27 \pm 2.82(\min : 0, \max : 12)$ \\
\hline Factor $3^{* * *}$ & 0.68 & $2.54 \pm 2.31(\min : 0, \max : 8)$ \\
\hline Scale total & $\mathbf{0 . 8 4}$ & $\mathbf{1 5 . 3 1 \pm 6 . 8 6}(\min : \mathbf{0}, \mathbf{m a x}: \mathbf{3 4})$ \\
\hline
\end{tabular}

SD: Standard deviation; Min: Minimum; Max: Maximum

Factor $1 *$ Sexual Function

Factor $2 * *$ Sexual Frequency

Factor $3 * * *$ Sexual Fear

\section{Table III: Results of Confirmatory Factor Analysis ( $\mathrm{n}=150)$.}

\begin{tabular}{lcccc}
\hline Fit indices for evaluation criteria & Abbreviation & Well - fitting & Acceptable & RSS - Tr \\
\hline Degree of freedom & Df & - & - & 30 \\
\hline P value & P & $0.05 \leq \mathrm{p} \leq 1$ & $0.01 \leq \mathrm{p} \leq .05$ & 0.019 \\
\hline $\begin{array}{l}\text { Minimum Fit Function Chi-Square to Degrees of } \\
\text { Freedom Ratio }\end{array}$ & $\chi^{2} / \mathrm{df}$ & $0 \leq / \mathrm{df} \leq 2$ & $2 \leq / \mathrm{df} \leq 3$ & 1.61 \\
\hline The root mean square error of approximation & RMSEA & $<0.05$ & $0.05-0.08$ & 0.07 \\
\hline Standardized root mean square residual & SRMR & $<0.05$ & $0.05-0.10$ & 0.05 \\
\hline Normed Fit Index & NFI & $0.95-1.00$ & $0.90-0.95$ & 0.92 \\
\hline Non-Normed Fit Index & NNFI & $0.97-1.00$ & $0.95-0.97$ & 0.95 \\
\hline Comparative Fit Index & GFI & $0.97-1.00$ & $>0.90$ & 0.97 \\
\hline Goodness of Fit Index & GFI & $0.95-1.00$ & $>0.90$ & 0.94 \\
\hline Adjusted Goodness of Fit Index & AGFI & $0.90-1.00$ & $>0.85$ & 0.89 \\
\hline
\end{tabular}

RSS-Tr: Relationship and Sexuality Scale-Turkish. 
Table IV: Results of explanatory factor analysis.

\begin{tabular}{lccc}
\hline & \multicolumn{3}{c}{ Factors } \\
\cline { 2 - 4 } Items & F1* & F2** & F3*** \\
\hline Item 2 & 0.83 & & \\
\hline Item 8 & 0.81 & & \\
\hline Item 3 & 0.80 & & \\
\hline Item 7 & 0.70 & & \\
\hline Item 1 & 0.65 & & \\
\hline Item 6 & & 0.87 & \\
\hline Item 5 & & 0.77 & \\
\hline Item 10 & & & 0.82 \\
\hline Item 9 & & & 0.78 \\
\hline Item 4 & & & 0.51 \\
\hline Eigenvalue & 3.07 & 1.81 & 1.76 \\
\hline Cronbach's Alpha & 0.86 & 0.60 & 0.68 \\
\hline \% Variance Explained & 30.7 & 18.1 & 17.6 \\
\hline The Cumulative \% of Variance & 30.7 & 48.8 & 66.4 \\
\hline
\end{tabular}

$\mathrm{F} 1 *$ Sexual Function

F2** Sexual Frequency

F3*** Sexual Fear

Table V: Item-total correlation of the RSS- $\operatorname{Tr}(\mathrm{n}=150)$.

\section{RSS-Tr}

$\mathbf{r}$

$\boldsymbol{p}$

1. My sexual life has been negatively

affected since the onset of renal

$0.72 \quad 0.000$

transplantation.

2. Renal transplantation has affected my sexual desire.

$0.72 \quad 0.000$

3. Renal transplantation treatment has affected my sexual desire.

$0.77 \quad 0.000$

4. I am satisfied with the frequency of hugs and kisses.

0.450 .000

5. I am afraid of sexual intercourse.

$0.68 \quad 0.000$

6. I feel my partner is afraid of sexual intercourse.

$0.59 \quad 0.000$

7. The frequency of sexual intercourse has changed now as compared to

$0.61 \quad 0.000$ before renal transplantation.

8. My possibility to reach orgasm has $\begin{array}{lll}\text { changed now as compared to before } & 0.60 & 0.000\end{array}$ renal transplantation.

9. I am satisfied with my present frequency of sexual intercourse.

$0.67 \quad 0.000$

10.During the last two weeks I have had sexual intercourse.

$0.59 \quad 0.000$

RSS-Tr: Relationship and Sexuality Scale-Turkish; r= itemtotal correlation.
Table VI: Correlations between RSS-Tr total score and

subscale scores.

\begin{tabular}{lccc}
$\begin{array}{l}\text { Scale } \\
\text { sub-dimensions }\end{array}$ & $\begin{array}{c}\text { Scale } \\
\text { total }(\mathbf{r})\end{array}$ & $\begin{array}{c}\text { Factor } \\
\mathbf{1}\end{array}$ & $\begin{array}{c}\text { Factor } \\
\mathbf{2}\end{array}$ \\
\hline Factor 1 & $0.83^{* *}$ & & \\
\hline Factor $\mathbf{2}$ & $0.78^{* *}$ & $0.41 * *$ & \\
\hline Factor 3 & $0.70^{* *}$ & $0.36^{* *}$ & $0.46 * *$ \\
\hline
\end{tabular}

$* * \mathrm{p}<0.01$

Factor 1 - Sexual Function

Factor 2 - Sexual Frequency

Factor 3 - Sexual Fear

Furthermore, correlations between total scale score and sub-dimensions were at higher levels. These correlations were as follows: $r=0.83$ for sexual function, $r=0.78$ for sexual frequency, and $r=0.70$ for sexual fear (Table 6).

\section{Concurrent validity}

Correlation analysis was performed to investigate the relationship between the ASEX and RSS-Tr in terms of concurrent validity. A positive, moderate, and statistically significant relationship was observed between the RSS-Tr and $\operatorname{ASEX}(r=0.49 ; p=0.000)$. Correlation values $(r)$ ranged from 0.32 to 0.48 .

\section{DISGUSSION}

Although sexual dysfunction is a major health problem observed before and after $\mathrm{KT}$, there is no valid and reliable measurement tool in Turkish to measure the relationship and sexuality status of KT recipients. Based on this requirement, the present research was conducted to adapt the RSS to Turkish. In this section, results of RSS-Tr validity and reliability assessments are discussed.

For the model to be acceptable, the value of $\chi 2$ is evaluated by dividing by the $\mathrm{df}$. If this value is $\chi^{2} / d f \leq 2$, the model is a good model, while $\chi^{2} / d f \leq 5$ indicates that the model is acceptable (29). In the present study, $\chi 2 / d f=1.61$ was found to be a good fit. The RMSEA and SRMR values were equal to or less than 0.08 , which indicates that the model is well-fitting. In the present study, RMSEA was 0.07 and SRMR was 0.05, thus indicating that the model fit well. Normal values of CFI and GFI were $\geq 0.90$, which also confirms a good model fit. Since CFI $=0.97$ and GFI $=0.94$ in the present study, it was found to have a good fit. The results of sphericity for Bartlett's test were examined and were observed to be statistically significant $\left(\chi^{2}=589.56\right.$; $p=0.000$ ), while the correlation matrix was appropriate to conduct factor analysis of RSS-Tr items according to the results.

The factor structure of explanatory factor analysis for the RSS-Tr for KT recipients is provided in Table 4. Further- 
more, the three sub-dimensions were similarly obtained for the RSS-Tr and the original RSS. Factor 1 is named as "sexual function", factor 2 as "sexual frequency" and factor 3 as "sexual fear". Items 1, 2, 3, 7, and 8 are in sexual function, while items 4,9 , and 10 are in sexual frequency, and items 5 and 6 are in sexual fear. It is known that items with a factor load of less than 0.20 should be excluded (30). In the present study, item 4 had the lowest factor load (0.51), while item 6 had the highest load (0.87), and because there is no factor load below 0.20 no items were excluded. The general mean score of the RSS-Tr for KT recipients was $15.31 \pm 6.86$, while the subdimension of sexual function was $6.54 \pm 3.59$, the sub-dimension of sexual frequency was $6.27 \pm 2.82$, and the sub-dimension of sexual fear was 2.54 \pm 2.31 . It is known that high scores represent the presence of sexual dysfunction. According to the results of the present study, the total mean score of patients undergoing KT is considered low, since it is less than half of the score received from the scale. Lower scores indicate stronger relationship and sexuality. In the literature, higher scores are indicated as indicators of worse conditions (20,23). According to internal consistency results for the RSS-Tr, the general Cronbach's alpha of the scale was 0.84 . The coefficients of sub-dimensions were 0.86 for sexual function, 0.60 for sexual frequency, and 0.68 for sexual fear. Moreover, the Cronbach's alpha value for sexual frequency was lower, since it consisted of twoquestions. Although the Cronbach's alpha of the sub-dimensions was lower, the KMO value of the scale was considered high. This situation requires the use of the entirescale, including all sub-dimensions. The RSS-Tr was generally considered highly reliable. In our study, the sub-dimension of sexual function explained $30.7 \%$ of the total variance of the feature measured through this scale, while sexual frequency explained $18.1 \%$, and sexual fear explained $17.6 \%$ (Table 4). All three factors explained $66.4 \%$ of he total variance according to factor analysis. In the original article by Berglund et al., the subdimension of sexual function explained $35 \%$ of the total variance of the feature measured through this scale, while sexual frequency explained $15 \%$, and sexual fear explained 12\% (19). Item-total correlations should also be made in the sub-dimensions. Item total correlation is expected to be positive and greater than 0.25 (28).
Correlations between total scale score and sub-dimensions were at high levels, with $r=0.83$ for sexual function, $r=0.78$ for sexual frequency, and $r=0.70$ for sexual fear. No items were excluded because there were no item-total scores less than 0.25 , and the internal consistency of the test was determined to be high.

Sexual dysfunction is a major health problem observed before and after KT. Appropriate interventions are required for patients suffering from sexual problems after KT. To determine these interventions, a measurement tool that can assess sexual function, fear, and frequency in KT patients is required. The content validity, construct validity, and reliability analyses of the RSS-Tr revealed that the scale may be used to measure the relationships and sexuality of KT recipients in Turkey.

\section{CONGLUSION}

The RSS-Tr is an easily applicable scale consisting of 10 items and 3 factors. It is a reliable and highly valid tool for assessing the relationships and sexuality of individuals following KT.

Ethics Committee Approval: Ethics committee approval was received for this study from the ethics committee of Akdeniz University (decision no. 2016/427).

Informed Consent: Written informed consent was obtained from participants who participated in this study.

Author Contributions: Concept - M.G.A.; Design M.G.A.; Supervision - M.G.A., N.A.; Resources - M.G.A.; Materials - M.G.A.; Data Collection and/or Processing M.G.A.; Analysis and/or Interpretation - M.G.A., N.A.; Literature Search - M.G.A., N.A.; Writing Manuscript M.G.A.; Critical Review - M.G.A., N.A.; Other - M.G.A.

Conflict of Interest: The authors declare no conflicts of interest.

Financial Disclosure; The authors completed the manuscript without the aid of any type of funding. 


\section{REFERENGES}

1. Aitbaev KA, Murkamilov IT, Fomin VV. Hypolipidemic Therapy and Chronic Kidney Disease: Effects on Cardiovascular Risks and Renal Dysfunction. Kardiologiia 2019;59(2):79-87.

2. World Kidney Day. Chronic Kidney Disease. [cited 2019 Jun 5]. Available from: https://www.worldkidneyday.org/ facts/chronic-kidney-disease/.

3. Süleymanlar G, Ateş K, Seyahi N. Registry of the Nephrology, Dialysis and Transplantation in Turkey. Ankara: By the Turkish Society of Nephrology; 2017. [cited 2019 May 9]. Available from: http://www.nefroloji.org.tr/ folders/file/18104_REGISTRY2017_kontrol_vl.pdf

4. Heng AE, Montaurier C, Cano N, Caillot N, Blot A, Meunier N, Pereira B, Marceau G, Sapin V, Jouve C, Boirie Y, Deteix P, Morio B. Energy expenditure, spontaneous physical activity and with weight gain in kidney transplant recipients. Clinical Nutrition. 2015;34(3):457-464.

5. World Health Organization (WHO). Defining sexual health: report of a technical consultation on sexual health, 28-31 Jan 2002. Geneva. [cited 2018 Sep 13]. Available from: https://www.who.int/reproductivehealth/publications/sexual_health/defining_sexual_health.pdf

6. Ergün G, Çakır C. School of health science's senior students of knowledge, attitudes and behavivour properties about sexual health. Acibadem University Health Sciences Journal 2015;6(2):99-104.

7. Sabanciogullari S, Taşkın Yılmaz F, Güngör FI, Söylemez $\mathrm{S}$, Benli RB. Sexual function in patients with chronic renal failure on hemodialysis and its effects on patients' perception of health and life satisfaction. Sexuality and Disability. 2015;33(2);175-186.

8. van Ek GF, Krouwel EM, van der Veen E, Nicolai MPJ, Ringers J, Den Oudsten BL, Putter H, Pelger RCM, Elzevier HW. The discussion of sexual dysfunction before and after kidney transplantation from the perspective of the renal transplant surgeon. Progress in Transplantation. 2017;27(4):354-59.

9. Sikora-Grabka E, Adamczak M, Kuczera P, Wiecek A. Serum sex hormones concentrations in young women in the early period after successful kidney transplantation. Endokrynologia Polska. 2018;69(2):150-55.

10. Mirone V, Longo N, Fusco F, Verze P, Creta M, Parazzini F, Imbimbo C. Renal transplantation does not improve erectile function in hemodialysed patients. European Urology. 2009;56(6):1047-1054.

11. Seyahi N, Ateş K, Süleymanlar G. Current status of renal replacement therapies in Turkey: Turkish Society of Nephrology Registry 2014 summary report. Turkish Journal of Nephrology. 2016;25(2):135-141.
12. Pertuz W, Castaneda DA, Rincon O, Lozano E. Sexual dysfunction in patients with chronic renal disease: Does it improve with renal transplantation? Transplantation Proceedings. 2014;46(9):3021-3026.

13. United States Renal Data System (USRDS). GKD in the United States. 2016 USRDS Annual Data Report, Volume 1. [cited 2019 Jan 8]. Available from: https://www. usrds.org/2016/download/v1_c01_Gen_Pop_16.pdf

14. Özşaker E. Transplantation and quality of life. Balıkesir Health Sciences Journal 2014;3(3):166-73.

15. Şahin AF, Cihan A, Akgül K,Demir Ö, Gürkan A, Çelik A, Can E, Esen AA. Sexual functions after renal transplantation in males. Turkish Journal of Urology 2009; 35(1):23-27.

16. Antonucci M, Palermo G, Recupero SM, Bientinesi R, Presicce F, Foschi N, Bassi P, Gulino G. Male sexual dysfunction in patients with chronic end-stage renal insufficiency and in renal transplant recipients. AArchivio Italiano di Urologia e Andrologia 2016;87(4):299-305.

17. Birol L. Hemşirelik Süreci - Hemşirelik Bakımında Sistematik Yaklaşım. İzmir: Etki Matbaacılık; 2009.

18. Polit DF, Beck CT. Essentials of nursing research: Appraising evidence for nursing practice. (8th ed.). Philadelphia: Wolters Kluwer Health; 2013.

19. Berglund G, Nystedt M, Bolund C, Sjödén PO, Rutquist LE. Effect of endocrine treatment on sexuality in premenopausal breast cancer patients: a prospective randomized study. Journal of Clinical Oncology. 2001;19(11):27882796.

20. Kazemi-Saleh D, Pishgoo B, Farrokhi F, Fotros A, Assari S. Sexual function and psychological status among males and females with ischemic heart disease. The Journal of Sexual Medicine. 2008;5(10):2330-2337.

21. Tavallaii SA, Mirzamani M, Heshmatzade Behzadi A, Assari S, Khoddami Vishteh HR, Hajarizadeh B, Einollahi B. Sexual function: A comparison between male renal transplant recipients and hemodialysis patients. The Journal of Sexual Medicine 2009;6(1):142-148.

22. Ryan C, Sadlier M, De Vol E, Patel M, Lloyd AA, Day A, Lally A, Kirby B, Menter A. Genital psoriasis is associated with significant impairment in quality of life and sexual functioning. Journal of the American Academy of Dermatology. 2015;72(6):978-983.

23. Assari S, Ahmadi K, Kazemi Saleh D. Gender Differences in the Association between Lipid Profile and Sexual Function among Patients with Coronary Artery Disease. International Cardiovascular Research Journal. 2014;8(1):9-14.

24. McGahuey CA, Gelenberg AJ, Laukes CA, Moreno FA, Delgado PL, McKnight KM, Manber R. The Arizona Sexual Experience Scale (ASEX): reliability and validity. Journal of Sex \& Marital Therapy. 2000;26(1):25-40. 
25. Soykan A. The reliability and validity of Arizona Sexual Experiences Scale in Turkish ESRD patients undergoing hemodialysis. International Journal of Impotence Research. 2004;16(6):531-534.

26. World Health Organization(WHO). Process of translation and adaptation of instruments. 2017. [cited 2019 Jun 8]. Available from: http://www.who.int/substance_abuse/ research_tools/translation/en/

27. Ozdamar K. Ölçek ve test geliştirme yapısal eşitlik modellemesi: Ibm, Spss, Ibm Spss Amos ve Minitab uygulamalı. (1th ed.). Eskişehir: Nisan Kitabevi; 2016.
28. Alpar R. Spor, sağlık ve eğitim bilimlerinden örneklerle uygulamalı istatistik ve geçerlik güvenirlik (3th ed.). Ankara: Detay Yayıncılık; 2014.

29. Çapık C. Use of confirmatory factor analysis in validity and reliability studies. Journal of Anatolian Nursing and Health Sciences 2014:17(3);196-205.

30. Kılcan B, Çepni O, Kılınç AÇ. Development of the attitude towards refugee students scale. Journal of Human Sciences 2017;14(2):1045-1057. 